\title{
NORMATIVE, AND SOMEWHERE TO GO? REFLECTIONS ON PROFESSIONAL RESPONSIBILITY
}

\author{
RICHARD F. DEVLIN*
}

In this article the author offers some reflections on professional responsibility. He straddles the optimist and pessimist perspectives espousing "pessoptimism" as a more adequate position than either extreme. The author begins by deconstructing the title of the conference in which the paper was delivered: "A New Look: A National Conference on the Legal Profession and Ethics," which took place in Calgary, in June 1994.

Pursuing a middle path between the optimistic and pessimistic approaches to professional responsibility, the author outlines the parameters of his ethical vision which provides some directions for legal practice. There are three elements to his restructured ethical vision: the "talent" of critical self-reflexivity, the maxim to act responsibly and the injunction to do no harm.

The author draws two conclusions from his study: first, it is possible to talk about legal ethics and to outline some procedural and substantive ethical guidelines. Second, ethics are plural and diversified, contingent upon the nature of the "law job" involved.

Finally, the author attempts to locate the "ethical triad" in the context of several different aspects of the legal profession; in legal education, as law students, lawyers, judges, benchers and legislators. He suggests that the primary responsibility for improved legal service lies with those who are within the system and that legal ethics ought to be seen as enforceable "public" norms.

In conclusion, returning to the notion of "pessoptimism," the author advocates an optimistic approach but sets out reservations and cautions. In the end, the author hopes that if the legal community cannot agree to do more good, perhaps it can at least agree to do less harm.
L'auteur offre quelques réflexions sur la notion de responsabilité professionnelle. Il professe un certain "pessoptimisme», plus approprié selon lui que l'optimisme ou le pessimisme. Il commence par déconstruire le titre du congrès où il a présenté son article. "A New Look: A national Conference on the Legal Profession and Ethics», qui a eu lieu $\dot{a}$ Calgary en juin 1994.

Dans cette perspective intermédiaire, l'auteur définit les paramètres de sa vision éthique et propose quelques lignes directrices pour la pratique du droit. Cette vision éthique restructurée comprend trois éléments : le "don» d'auto-examen critique, la détermination d'agir de façon responsable et l'obligation de ne pas nuire.

L'auteur tire deux conclusions de son étude: premièrement, il est possible de parler d'éthique juridique et de décrire cerlaines directives éthiques procédurales et matérielles. Deuxièmement, l'éthique est plurielle et diverse, et dépend de la nature des tâches juridiques concernées.

Finalement, l'auteur tente de situer la triade éthique en abordant plusieurs aspects de la profession juridique - dans l'enseignement du droit, du point de vue des élèves, des avocats, des juges, des membres du conseil général du barreau et des législateurs. Il suggère que la responsabilité d'améliorer les services juridiques incombe avant tout à ceux qui sont à l'intérieur du système et que l'éthique devrait ètre perçue à titre de normes publiques exécutoires.

En canclusion, revenant à la notion de pessoptimisme, l'auteur opte pour une approche optimiste assortie de réserves et de mises en garde. L'auteur espère que, si la communauté juridique ne peut pas s'entendre pour faire plus de bien, tout au moins peut-elle s'accorder pour faire moins de mal.

\section{TABLE OF CONTENTS}

 \\ II. DECONSTRUCTING THE TITLE $\ldots \ldots \ldots \ldots \ldots \ldots \ldots 926$}

Associate Professor, Dalhousie Law School. Several students attended the concurrent sessions of the conference and provided me with helpful feedback. I would like to thank Kerri Branigan, Wendy Francis, David St. Pierre, Angela Tripathy and Stephanie Wilde, but acknowledge that the following comments reflect my own thoughts rather than theirs. Annie Finn provided additional research assistance. 
A. A NEW LOOK ..................... 926

B. A NATIONAL CONFERENCE ON THE

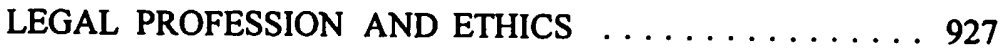

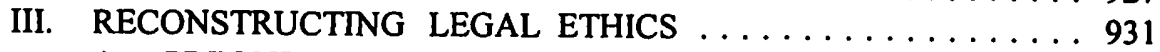

A. PRINCIPLE OF CRITICAL SELF-REFLEXIVITY $\ldots \ldots 931$

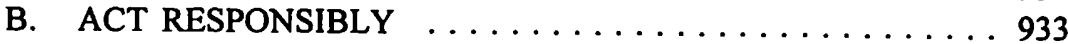

C. DO NO HARM .................. 935

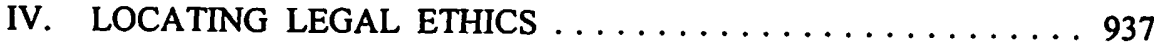

A. LEGAL EDUCATION $\ldots \ldots \ldots \ldots \ldots \ldots \ldots \ldots \ldots 9 . \ldots \ldots$

B. LAW STUDENTS $\ldots \ldots \ldots \ldots \ldots \ldots \ldots \ldots \ldots \ldots$

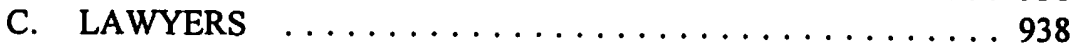

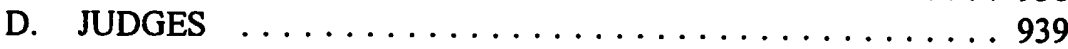

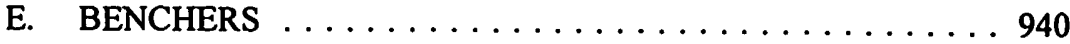

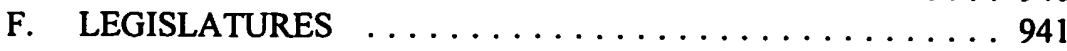

G. SUMMARY $\ldots \ldots \ldots \ldots \ldots \ldots \ldots \ldots \ldots \ldots \ldots \ldots \ldots \ldots$

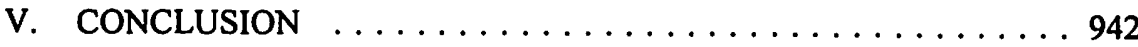

\section{INTRODUCTION}

On a previous occasion, several years ago, I served as a rapporteur for an international human rights conference hosted by the University of Calgary, and produced a paper entitled: "Solidarity or Solipsistic Tunnel Vision: Reminiscences of a Renegade Rapporteur." ' I must have done a reasonable job, as once again, I have been invited to try to pull things together. On this occasion, however, I hope to be less contentious, less of a juvenile delinquent and to offer a report entitled: "Normative, And Somewhere to Go?: Reflections on Professional Responsibility."22

To capture the essence of this report, it may be helpful to structure my comments around a fairly new word: pessoptimism. ${ }^{3}$ In the course of the conference there have been frequent references to "the cynics" or "the pessimists." These labels were attached to those participants who tend to be somewhat sceptical of the roles that modern lawyers perform, those who tend to believe that the concept of an ethically responsible lawyer is "oxymoronic." ${ }^{4}$ Participants who indulge in such labelling usually do so in a somewhat critical and distancing way, without, however, naming or labelling their own perspective. It may be appropriate, at least for heuristic purposes, to conceive of these other participants as "the optimists." They are, in a sense, "the faithful" in that

I R. Devlin, "Solidarity or Solipsistic Tunnel Vision?: Reminiscences of a Renegade Rapporteur" in K. Mahoney \& P. Mahoney, Human Rights in the Twenty First Century: A Global Challenge (Boston: M. Nijhoff, 1993) 991.

2 This article is, in part, an implied critique of P. Schlag, "Normative and No Where to Go" (1990) 43 Stan. L. Rev. 167.

3 I am grateful to Alison Outhit who first suggested this neologism to me. It might also be worth noting that when I presented this paper at the Conference, due to my accent several members of the audience thought I was coining yet another "ism": "pissedoffism." Though tempting, it is a concept I shall leave for another occasion.

- See A.C. Hutchinson, "Calgary and Everything After: A Postmodern Re-vision of Lawyering" (1995) 33 Alta. L. Rev. 768. 
they believe in the cause of professionally responsible legal practice and they are sanguine about the ethical future of the legal profession. The ensuing reflections straddle, rather uncomfortably, these competing perspectives. Hence the neologism "pessoptimism."

\section{DECONSTRUCTING THE TITLE}

The title of this conference is comprised of two components, separated by a colon: "a new look" and "a national conference on the legal profession and ethics." Each of these two subcomponents can, I think, be reviewed from both an optimistic and a pessimistic perspective.

\section{A. A NEW LOOK}

The pessimists tend to conceive of the idea of "a new look" as a public relations job, as an attempt to provide the profession with a better image to counteract quite widespread public disapproval and disapprobrium about the legal profession. ${ }^{5}$ They suggest that the underlying aspiration of a conference such as this is to spruce up the profession, to brush its hair, polish its teeth and give it a shiny new outfit. Despite (or perhaps, because of) such "professional apologetics," the pessimists argue that we are still left with the same petulant spoiled brat. In other words, all talk of a new look and legal ethics is but a legitimation strategy designed to offset a negative image generated by several recent high profile scandals (for example, the Lang Michener case), scandals that could endanger the monopoly position of the profession. ${ }^{7}$

Optimists are reluctant to adopt such an approach. ${ }^{8}$ They conceive of the phrase "a new look" not so much as an attempt to rectify an image problem, but rather as a process of revision. From an optimistic perspective, the ambition of a conference of this nature is to re-think, re-analyze and re-interpret the assumptions and norms of legal practice in all its forms. The suggestion is that perhaps we have been somewhat lax on

See e.g. the proposed role statement of the L.S.U.C. reproduced in C. Curtis, "Alternative Visions of the Legal Profession in Society: A Perspective on Ontario" (1995) 33 Alta. L. Rev. 787; J. Watson Hamilton, "Metaphors of Lawyers' Professionalism" (1995) 33 Alta. L. Rev. 833; J. Jaff, "Law and Lawyers in Pop Music: A Reason for Self-Reflection" (1986) 40 U. Miami L. Rev. 659. There are also indications of dissatisfaction with the practice of law within the profession. See e.g. A. Altman, "Modem Litigators and Lawyer Statesmen" (1994) 103 Yale L.J. 1031 at 1033; G. Giesel, "The Business Client is a Woman: The Effect of Women as In-House Counsel on Women in Law Firms and the Legal Profession" (1993) 72 Nebr. L. Rev. 760 at 783-86. W. Pue, "In Pursuit of Better Myth: Lawyers History and History of Lawyers" (1995) 33 Alta. L. Rev. 730 at 734.

7 R. Abel, "Toward a Political Economy of Lawyers" (1981) Wis. L. Rev. 1117; H. Arthurs, "Climbing Kilimanjaro: Ethics for Postmodern Professionals" (1993) 6:1 Westminster Affairs 3 at 6; G. MacKenzie, "Lawyer Discipline and the Independence of the Bar: Can Lawyers Still Govern Themselves?" (1990) 24 L. Soc. Gaz. 319; G. MacKenzie, Lawyers and Ethics: Professional Responsibility and Discipline (Toronto: Carswell, 1993); Pue, supra note 6; B. Wilson, "Pressing Ethical Questions Facing the Legal Profession" (1993) 6:1 Westminster Affairs 80.

8 M. Somerville, "Applying Ethical Standards to Lawyers" (1993) 6:1 Westminster Affairs 11 at 12, 14. 
issues of legal ethics, but that time has now come to re-orient the profession. This approach is optimistic in the sense that it believes that reform and transformation of the legal profession are possible. Thus, for example, we have MacKenzie's affirmation of the impending detailed code in Alberta, ${ }^{9}$ Garant's celebration of the new protocol on interjurisdictional practice and its suggested "innovative ethics" provisions, ${ }^{10}$ the proposed role statement of the L.S.U.C.," and the call by Mr. Justice Major for more pro bono work. ${ }^{12}$

\section{B. A NATIONAL CONFERENCE ON THE LEGAL PROFESSION AND ETHICS}

In my opinion, probably the most significant word in the latter part of the title is "ethics." While the conference organizers obviously put a great deal of effort into convening a forum open to a variety of perspectives on the legal profession and ethics - perspectives informed by legal history, ${ }^{13}$ legal theory, ${ }^{14}$ personal experiences of discrimination and marginalization ${ }^{15}$ and official status within professional organizations $^{16}$ - I was quite disappointed that not a lot of attention was focused upon what is meant by "ethics." By and large the tendency was to consider the meaning and parameters of "ethics" to be uncontroversial and to proceed without caution. ${ }^{17}$ As a partial corrective to this discursive lacuna, it may be helpful to develop some tentative thoughts on what ethics might mean and to locate some of the debates that have occurred during the conference in the context of these reflections on ethics. Once again the pessimism/optimism dichotomy may serve as a helpful lens through which to filter these propositions.

Pessimists tend to be wary of ethics talk on both an epistemological and pragmatic level. Epistemological pessimists tend to conceive of ethics as a cognate of some

G. MacKenzie, "The Valentine's Card in the Operating Room: Codes of Ethics and the Family Ideals of the Legal Profession" (1995) 33 Alta. L. Rev. 859.

P. Garant, "A Reactionary Looks to the Future" (Address to A New Look: A National Conference on the Legal Profession and Ethics, Calgary 10 June 1994) [unpublished].

1 Curtis, supra note 5.

12 J.C. Major, "Lawyer's Obligation to Provide Legal Services" (1995) 33 Alta. L. Rev. 719. But see contra B. Ballman Jr., "Amended Rule 6.1: Another Move Towards Mandatory Pro Bono? Is That What We Want?" (1994) 7 Geo. J. Legal Ethics 1139; S. Bretz, "Why Mandatory Pro Bono is a Bad Idea" (1990) 3 Geo. J. of Legal Ethics 623.

Pue, supra note 6.

Hamilton, supra note 5 .

D. Pothier, "On Not 'Getting It'" (1995) 33 Alta. L. Rev. 817.

D. McCawley, Address on "Regulation of the Profession" (A New Look: A National Conference on the Legal Profession and Ethics, Calgary 10 June 1994) [unpublished].

17 There is, of course, an extensive literature on the nature and function of legal ethics. See e.g. D. Luban, ed., The Good Lawyer: Lawyers' Roles and Lawyers' Ethics (Totowa, N.J.: Rowman \& Allanheld, 1983); D. Luban, Lawyers and Justice: An Ethical Study (Princeton: Princeton University Press, 1988); T. Shaffer, On Being a Christian Lawyer (Provo, Utah: Brigham Young University Press, 1981); T. Shaffer, American Lawyers and their Communities: Ethics in the Legal Profession (Notre Dame: University of Notre Dame Press, 1991). For a brief introductory overview, see C. Wolfram, Modern Legal Ethics (St. Paul Minn.: West Publishing Co., 1986) at 68-78. 
universalizing truth. ${ }^{18}$ Drawing on the insights of philosophical relativism, they tend to dismiss the possibility of Truth - with a capital $\mathrm{T}$ - and concomitantly the possibility of ethical discourse. ${ }^{19}$ Pragmatic pessimists tend to look to either history or sociology and argue that what is important in structuring legal practice is not an idealist regime of "ethics" but materially driven structural forces. ${ }^{20}$

Optimists, unsurprisingly, are unwilling to totally abandon the language of ethics. For some, legal ethics may be conceived of as a very precise set of rules or codes of conduct that, like rules of law, can provide guidance for proper action in specific situations. ${ }^{21}$ Mimicking the common law regime, the governing ideal of this perspective is essentially one of inductive logic, and so, in a sense, the more detailed and precise the rules, the better. ${ }^{22}$ An alternative optimistic approach is to consider ethics to be a universalizing and generalizing mode of reflection which, with the appropriate application of deductive logic, can provide guidance on how to proceed in moments of doubt. It is thought that the articulation of general principles can provide a structure of reflection and understanding that can be adopted to precise situations of moral complexity. ${ }^{23}$

At this point I want to temporarily bypass the arguments of the pessimists (though I will return to them in due course) to propose that each of the foregoing optimistic approaches - the inductive and the deductive - potentially have something to offer as we discuss the possibility of ethics for the legal profession. ${ }^{24}$ More specifically, I

12 Hutchinson, supra note 4.

19 Schlag, supra note 2.

20 H. Arthurs, "The Dead Parrot: Does Professional Self Regulation Exhibit Vital Signs?" (1995) 33 Alta. L. Rev. 800; Arthurs, supra note 7; Pue, supra note 6.

21 F. Zacharias, "Specificity in Professional Responsibility Codes: Theory, Practice and the Paradigm of Prosecutorial Ethics" (1993) 69 Notre Dame L. Rev. 223.

22 See Law Society of Alberta, Code of Professional Conduct (Calgary: Law Society of Alberta, 1995) [hereinafter Alberta Code].

23 As Law points out, this is very much the approach adopted by the ABA Canons of Ethics 1908, and CBA Canons of Legal Ethics 1920. J. Law, "A Code for All Reasons: The 1908 ABA and 1920 CBA Codes of Conduct in Retrospect" (Address to A New Look: A National Conference on the Legal Profession and Ethics, Calgary 10 June 1994) [unpublished]. One American commentator outlines the following six "principles":

1. Honesty. Don't steal. Bill fairly.

2. Candor. Tell the truth. Explain the significance of things.

3. Competence. Know what you are doing and do it well.

4. Diligence. Work hard and stick to it.

5. Loyalty. Use your independent professional judgment. Don't allow your own interests or the interests of others to divert, dilute, or diminish your efforts.

6. Discretion. Don't gossip. Don't reveal confidential information.

M. Bayles, Professional Ethics (Delmont, Calif.: Wadsworth Publishing Co., 1981). For a helpful overview of some of the different moral traditions that might be invoked, see $S$. Sherwin, No Longer Patient: Feminist Ethics and Health Care (Philadelphia: Temple University Press, 1992) at 35-42.

24 See also G. MacKenzie, supra note 9; and Nussbaum, who calls for "a conception of equitable judgment that is historically situated, responsive to particular circumstances, and yet committed to general norms of justice." in M. Nussbaum, "Scepticism about Practical Reason in Literature and the Law" (1994) 107 Harv. L. Rev. 714 at 743. 
think that there are two basic points to be made: first, ethical thought is best conceived of as pluralist and context sensitive; second, ethical commitment entails a belief in political correctness.

To elaborate: on occasion, some commentators suggest that there is such a thing as $a$ professional legal ethic that encompasses several specific virtues such as honour, honesty, integrity, loyalty and neutrality. ${ }^{25}$ Such an approach advocates a singular model of the legal professional persona. However, as several participants have argued, the legal profession is neither monolithic nor homogeneous; it is demographically diverse, ${ }^{26}$ stratified in its tasks, and pluralistic in its functions. ${ }^{27}$ Given these sociological realities, ${ }^{28}$ it seems to me that it is more appropriate to abandon singular (and therefore restrictive) modes of analysis and to approach ethics from the bottom up rather than from the top down. In other words, what is required is a contextual and pluralist conception of legal ethics, one that is contingent upon the nature of the particular "law jobs" in which a lawyer finds her or himself. ${ }^{29}$ Thus, questions of ethical conduct will depend upon whether one is acting as a litigator or as a counsellor, in a criminal context or a civil context, in an educational role or a representative role. Much might also depend upon how sophisticated a client might be, whether she or he is a "first timer" or a corporate "repeat player." ${ }^{30}$ Alberta seems to have moved in the direction of this complex, multi-tiered and contextually-sensitive approach. ${ }^{31}$

This point about a pluralistic and contextual approach to ethics is helpful in that it is potentially more pragmatic than the singular and abstracting approach. ${ }^{32}$ However, while it is procedurally useful insofar as it locates ethically reflective thought, it provides little substantive guidance as to how one is to do the right thing. For some, the answer is obvious: the lawyer should not abuse or take advantage of his or her client in whichever of the contexts one operates. My own view, however, is that such a mantra is both simplistic and inadequate. While it provides a necessary component for professionally responsible conduct, it is not sufficient. Ethics, I suggest, is about "right living" in all aspects of one's professional life. More precisely, ethical legal practice has both an internal and an external dimension.

The external dimension is quite obvious: it addresses questions about how one is to relate to one's client. As an advisor to, and representative of, one's client, the lawyer

A.D. Hunter, "A View as to the Profile of a Lawyer in Private Practice" (1995) 33 Alta. L. Rev. 831.

Report of the C.B.A. Task Force on Gender Equality in the Legal Profession, Touchstones for Change: Equality, Diversity and Accountability (Ottawa: Canadian Bar Association, 1993) [hereinafter Touchstones].

Arthurs, supra note 20; Curtis, supra note 5; Hutchinson, supra note 4.

See more generally R. Abel \& P. Lewis, Lawyers in Society: The Common Law World (Berkeley: University of California Press, 1988).

MacKenzie, Lawyers and Ethics, supra note 7 at 3; S. Sponkin, "The Need for Separate Codes of Professional Conduct for the Various Specialities" (1993) 7 Geo. J. Legal Ethics 149.

D. Wilkins, "Who Should Regulate Lawyers?" (1992) 105 Harv. L. Rev. 801 at 816-17.

Alberta Code, supra note 22.

Sherwin, supra note 23 at 53,77 . 
should act as a good faith agent. ${ }^{33}$ Now, while this is the familiar realm of professional responsibility, it is not easy to provide solutions to commonplace problems such as disclosure of confidential information, ${ }^{34}$ conflict of interest scenarios ${ }^{35}$ or more controversial issues such as cross-examination of a complainant in sexual assault situations or whistle blowing. ${ }^{36}$

The internal dimension is less obvious in the sense that, historically, it has not been conceived of as an issue of professional ethics. Basically, the internal dimension addresses the question of the lawyer's relationship with others with whom he or she comes into contact in his or her professional role. It asks: how do $\mathrm{l}$, as a lawyer, treat my clients, my colleagues, my employees? Are the norms and mores of my professional interaction premised upon, and enforcing of, attitudes that are dominating and exploitative? ${ }^{37}$ In other words, it asks: do I contribute to an environment in which, inter alia, classism, racism, sexism, homophobia and abilism are accepted and tolerated $?^{38}$ More challenging still, it forces us to consider whether we are aware of the interaction of different forms of domination and exclusion. ${ }^{39}$ For example, what efforts do we pursue in attempting to understand and respond to the specific circumstances of a disabled woman or a gay First Nations person?

For some, this turn to an internal interrogation of professional norms and mores may go too far. It may be understood as being a form of moralistic interventionism or even political correctness. ${ }^{40}$ It may be perceived and construed as an unwarranted infringement of the rights of the autonomous lawyer to exercise his or her free choice to run a practice as she or he might wish. ${ }^{41}$ In short, some might claim that such an expanded conception of "professional responsibility" renders the phenomenon

B. Smith, Professional Conduct for Canadian Lawyers (Toronto: Butterworths, 1989).

See e.g. G. Grenier, "Solicitor-Client Privilege and the Ontario Loan and Trust Corporations Act" (1989) 15 Can. Bus. L.J. 129.

G. Steele, "Imputing Knowledge from One Member of a Firm to Another: 'Lead us Not into Temptation'" (1991) 12 Advocates Q. 46; P. Moser, "Chinese Walls: A Means of Avoiding Law Firm Disqualification When a Personally Disqualified Lawyer Joins the Firm" (1990) 3 Geo. J. Legal Ethics 399. MacKenzie proposes that detailed rules should be adopted to provide lawyers with guidance in such issues (Lawyers and Ethics, supra note 7). See also Wolfram, supra note 17, c. $6,7,8$.

R. Cramton, "The Lawyer as Whistleblower: Confidentiality and the Government Lawyer" (1991) 5 Geo. J. Legal Ethics 291; Wolfram, ibid. at 666.

For discussions of this point, see M. Harrington, Women Lawyers: Rewriting the Rules (New York: A.A. Knopf, 1994).

W. Baker, "Structure of the Workplace or Should we Continue to Knock the Comers off the Square Pegs or Can we Change the Shape of the Holes?" (1995) 33 Alta. L. Rev. 821; Curtis, supra note 5; MacKenzie, Lawyers and Ethics, supra note 7 at 25-24; Touchstones, supra note 26. Pothier, supra note 15; Touchstones, ibid.

My own view is that, despite the reactionary rhetoric, it is both acceptable and desirable to be politically correct, particularly if one is a lawyer. It seems to me that as professionals who seek to connect ourselves to justice we should seek to do the correct thing - and to take proper political stances to support our moral vision. Who, in good conscience, would want to act against their moral principles? Literally, why would you want to do the wrong thing, or be politically incorrect?

Curtis, supra note 5 . 
unrecognizable. Others may invoke the familiar refrain that academics may be good at critique but have little to offer by way of alternatives.

In response to these concerns, the next section will outline the parameters of an ethical vision that, in my opinion, provides some direction for legal practice.

\section{RECONSTRUCTING LEGAL ETHICS}

The reconstructive ethical vision advanced in this section is comprised of three basic elements: the "talent" of critical self-reflexivity; the maxim to act responsibly; and the injunction to do no harm ${ }^{42}$ - each of which can provide an angle on some of the presentations and debates that have occurred in the course of this conference.

\section{A. PRINCIPLE OF CRITICAL SELF-REFLEXIVITY}

As human beings who seek to do our jobs, to operate efficiently, to make a living and to sleep at night, we necessarily have a vested interest in believing that we are doing the right thing. However, at times there is danger of complacency, passivity, and routinization that can lead to "conceptual limitations of vision," ${ }^{43}$ or a sort of moral numbness. Certain patterns of professional conduct are so taken for granted that they may become entrenched and, therefore, unquestionable.

The principle of critical self-reflexivity works on the assumption that nothing is infallible and that everything is potentially up for grabs. ${ }^{44}$ It serves as a sort of ethical "pin prick" and encourages each of us to become conscious of the particular, partial, partisan and necessarily incomplete nature of our own self-perceptions. The principle of critical self-reflexivity suggests that each of us should do a "double take" on our assumptions, beliefs and conduct, to consider what possible gaps or failures might permeate our thinking and our practices. In other words, it demands that we build into both our analyses and conduct processes of ongoing self-recognition and that we foster a stronger disposition for humility and a greater openness to possible criticisms. An example might be that we advocates of the adversarial common law system could

42 Others have also discussed aspects of each of these ideas but none, I think, have put them together in quite the same way as I suggest. See e.g. S. Allegretti, "Shooting Elephants, Serving Clients: An Essay on George Orwell and the Lawyer-Client Relationship" (1993) Creighton L. Rev. 1; N. Cahn, "A Preliminary Feminist Critique of Legal Ethics" (1990) 4 Geo. J. Legal Ethics 23; D. Kennedy, "The Responsibility of Lawyers for the Justice of their Causes" (1987) 18 Tex. Tech. L. Rev. 1157; M. Nussbaum, supra note 24; S. Pepper, "Autonomy, Community and Lawyers' Ethics" (1990) 19 Capital U. L. Rev. 939; D. Rhode, "Ethical Perspectives on Legal Practice" (1985) 37 Stan. L. Rev. 589; W. Simon, "The Ideology of Advocacy: Procedural Justice and Professional Ethics" (1978) Wis. L. Rev. 30; W. Simon, "Ethical Discretion in Lawyering" (1988) 101 Harv. L. Rev. 1083.

4 See generally R.M. Unger, Social Theory, its Situation and its Task (Cambridge: Cambridge University Press, 1987). 
consider backing off from imposing our culturally specific legal norms and processes on First Nations peoples. ${ }^{45}$

More schematically, the principle of critical self-reflexivity might operate at both the macro and micro levels of the Canadian legal system. For example, at the macro level it might engender the following sorts of questions: is the practice of law complicitous in, or legitimizing of, patterns of inequality in Canadian society? Specifically, who tends to get access to law school, law jobs, and the "pick of the crop" opportunities within the profession? ${ }^{46}$ Are the assumptions that underpin contemporary legal practice as secure as we have traditionally believed? For example, is the adversarial model necessarily the most desirable route to follow given the radical diversity of legal problems in modern society? ${ }^{47}$ Are the traditional norms and standards for the evaluation of the legal profession sufficient to meet the needs of contemporary Canadian society? Do we need supplementary norms such as the desiderata of greater inclusion and the minimization of inequality ${ }^{48}$ Do we have an equitable distribution of legal resources in Canadian society $?^{49}$ Have there been information or market failures or negative externalities that have resulted in a dysfunctional or inefficient allocation of our legal wealth? $?^{50}$ If so, what sort of correctives can be developed? Is self-regulation by a monopoly really defensible on principled, practical or historical grounds? ${ }^{51}$

If all of these concerns seem to be so grand as to be imponderable, perhaps we can adopt the environmentalist slogan "think globally, act locally" to consider the application of the principle of self-reflexivity at the micro level of legal practice. First, this might suggest that each of us should consider the way in which the privilege of legal knowledge confers upon us social power. In turn, we might then want to question whether we use that dynamic of power/knowledge appropriately when we work with

L. Chartrand, "The Appropriateness of the Lawyer as Advocate in Contemporary Aboriginal Justice Initiatives" (1995) 33 Alta. L. Rev. 874. See also D. Kleinberger, "Wanted: An Ethos of Personal Responsibility - Why Codes of Ethics and Schools of Law Don't Make for Ethical Lawyers" (1989) 21 Con. L. Rev. 365 at 367-68, for a review of the criticisms of the adversarial model more generally.

Giesel, supra note 5, reviews the extensive American literature raising these concerns. In the Canadian context, see C. Tennant, "Discrimination in the Legal Profession, Codes of Professional Conduct and the Duty of Non-Discrimination" (1992) 15 Dalhousie L.J. 464; Touchstones, supra note 26.

D. Ginn, "Wife Assault, the Justice System and Professional Responsibility" (1995) 33 Alta. L. Rev. 908; Simon, "Ideology," supra note 42.

J. Dooley \& E. Wood, "Opening the Courthouse Door: The Americans with Disabilities Act's Impact on the Courts" (June-July 1992) 76 Jud. 39; Pothier, supra note 15; Touchstones, supra note 26.

49 See Major, supra note 12.

so D. Rhode, "Why the ABA Bothers: A Functional Perspective on Professional Codes" (1981) 59 Tex. L. Rev. 689 at 716.

51 Arthurs, supra note 20; Rhode, ibid. at 718; B. Stephenson, "The Social Contract of a Self Governing Profession" (1980) 14 L. Soc. Gaz. 255. 
our clients or whether we use it as a way to dominate them. ${ }^{52}$ Moreover, the principle of critical self-reflexivity might encourage us to reconsider the norms of our work environments and the particular roles that we find ourselves in as partners, associates, judges, clerks, students, professors, employees, employers and colleagues.

It is, of course, always easier to espouse the principle of self-reflexivity than it is to embrace it. To incorporate self-reflexivity into our lives and practices is a profound challenge. On one level, many of us are so busy that we cannot imagine secondguessing our normal assumptions because the result, we fear, might be chaos. On another level, it is painful to be told that individually and as a profession we are elitist, racist, abilist, classist and sexist. It is disturbing to realize that one's chosen profession may be part of the problem, when all along we thought that we were part of the solution. ${ }^{53}$ It is simply too exhausting to lose sleep at night pondering these questions when we have been hosting some potential clients for dinner and our daybook indicates a 7:00 a.m. power breakfast for the next morning. However, it seems to me that if one genuinely aspires to be more than a mere technical automaton or to have any pretence of being involved in a profession that holds itself out as closely connected to justice, then the principle of critical self-reflexivity is a minimal moral imperative.

In short, the principle of critical self-reflexivity is supplementary in that it advocates different analyses, focuses on different problems and frequently proposes different answers from those generated by conventional wisdom about professional responsibility. ${ }^{54}$ In a sense, it can be understood as a form of consciousness-raising and, as such, it destabilizes our "right not to know." ${ }^{55}$ Most importantly, the principle of critical self-reflexivity encourages us to reconsider the power that we as a profession possess. It helps us to remember that the professional is the political.

\section{B. ACT RESPONSIBLY}

While the principle of critical self-reflexivity may serve as a minimal moral imperative, it is, 1 fear, excessively procedural and therefore a little too minimal. One may practice critical self-reflexivity and still decide to act in what I would suggest is an unethical way. All that critical self-reflexivity would achieve is an awareness of the significance of one's acts. Changed consciousness is not changed circumstances.

Chartrand, supra note 45; Hutchinson, supra note 4; G. Lopez, Rebellious Lawyering: One Chicano's Vision of Progressive Law Practice (Boulder, Colo.: Westview Press, 1992); Pepper, supra note 42 at 949, 955; D. Rosenthal, Lawyer and Client: Who's in Charge? (New York: Russell Sape Foundation, 1974). Sexual relations with a client are an obvious example. It should be pointed out, however, that unlike many other professions, the legal community is at least asking questions about discrimination in the profession, and in this sense can be seen to be manifesting some of the virtues of self-reflexivity. See e.g. Touchstones, supra note 26. than male lawyers. See e.g. R. Jack \& D. Crowley Jack, Moral Vision and Professional Decisions: The Changing Values of Women and Men Lawyers (Cambridge: Cambridge University Press, 1989); C. Menkel-Meadow, "Portia in a Different Voice: Some Speculations on a Women's Lawyering Process" (1985) 1 Berkeley Women's L.J. 39. 
Therefore, I would argue that the principle of critical self-reflexivity also needs to be supplemented with some substantive content: the proposition to act responsibly.

As North American lawyers, we are ensconced in a tradition that puts a very high value on individualism, liberty and freedom. More specifically, there is a tendency to priorize rights thinking and to encode much social interaction and conflict in a rights discourse. In the context of this conference, two aspects of rights thinking may be pertinent: clients' rights and lawyers' rights.

The idea of client's rights dovetails with the lawyerly ethos of zealous representation. ${ }^{56}$ That is, conventional professional wisdom argues that the client (as principal) has absolute priority and that it is the duty of the lawyer (as agent) to represent that client to the full extent of her or his capacities without, however, either in perception or reality, ever actually identifying with that particular client. The assumptions underlying "this Principle of Nonaccountability" ${ }^{157}$ are threefold: first, that client autonomy is the paradigm value ${ }^{58}$ second, that judgments by lawyers in relation to a client are both premature and partisan; and third, that distance is essential to ensure rational conduct. ${ }^{59}$ The result, to put it crassly, is the "hired gun," ${ }^{60}$ or to be more polite, the "neutral partisanship." ${ }^{61}$

The idea of lawyers' rights arises out of a commingling of at least two assumptions: the belief that a lawyer, like everyone else, has a right to make a living doing what she or he does best; ${ }^{62}$ and the idea that the protection of such a lawyerly right serves the public good of ensuring that everyone will have access to legal representation, because lawyers will not be unwilling to represent "unpopular" clients. ${ }^{63}$

There is no doubt that rights discourse is an important social achievement and that arguments in favour of both lawyers' and clients' rights carry a great deal of weight. However, we must be careful not to get carried away with the rhetoric of rights. An excessive emphasis on rights can induce a form of professional tunnel vision.

See e.g. Law Society of Alberta, Professional Conduct Handbook (Calgary: Law Society of Alberta, 1983) at 27:

When acting as an advocate the lawyer must, while treating the tribunal with courtesy and respect, represent his [sic] client resolutely, honourably, and within the limits of the law.

See also J. Law, supra note 23 for a further discussion of the idea of zealous representation. Murray Schwartz has probably stated this position most succinctly: "When acting as an advocate... a lawyer is neither legally, professionally nor morally accountable for the means used or the ends achieved." M. Schwartz, "The Professionalism and Accountability of Lawyers" (1978) 66 Cal. L. Rev. 669 at 673.

S. Pepper, "The Lawyer's Amoral Ethical Role: A Defence, A Problem, and Some Possibilities" (1986) Am. Bar Found. Res. J. 613.

Kleinberger, supra note 45 at 370-71.

M. Freedman, "The Lawyer as a Hired Gun" in A. Gerson, ed., Lawyer's Ethics: Contemporary Dilemmas (New Brunswick, N.J.: Transaction Inc., 1980) 63.

Rhode, supra note 42 at 605; Simon, "Ideology," supra note 42 at 36-37.

Rhode, ibid. at 610.

Major, supra note 12. Rhode, however, argues that in the American context the legal profession has repeatedly failed to represent unpopular causes. Rhode, ibid. at 630 . 
Specifically, by exclusively highlighting the lawyer-client relationship, the broader context in which we as a profession operate may be obscured, rendering our conduct disconnected from the broader community. ${ }^{64}$

To my mind, the practice of law is not a right; rather it is a socially conferred privilege. To be a lawyer is to be a trustee not just for the interests of individual clients, but also for the interests of the broader society. If this is so, greater attention must be focused on the responsible fulfilment of this socially conferred trust. Consequently, it is not adequate to fetishize rights to justify a "my hands are clean" argument. Rather, as public trustees, lawyers must recognize their social responsibilities and be accountable for their conduct. ${ }^{65}$ Thus, as we perform our various legal practices, not only must we ask the unavoidable question of what the client's rights are, but also the parallel question of what the ramifications of our conduct and strategies are for the broader society. Lawyers who advise clients on environmental issues might be an obvious example as might criminal defence lawyers in sexual assault trials.

\section{DO NO HARM}

While the proposition to act responsibly adds some substantive bite to the principle of critical self-reflexivity, it is still too abstracted. Therefore, as a third side to this ethical triad I would suggest that lawyers consider the maxim: do no harm with your legal skills or in the operation of your legal practice.

On one level this would easily translate into the banal imperative to do no harm to your client: pay attention to your job, don't over-bill, maintain confidences and don't steal the trust funds. A more ambitious, expansive and controversial application of the maxim would, however, counsel that lawyers should not use their legal skills to harm others in society, beyond their clients. ${ }^{66}$ This would mean that, while lawyers have a responsibility to pursue the interests of their clients, they cannot go so far that their conduct would cause harm to others. The challenge of such a maxim becomes obvious when it is counterposed with one of the classic statements of the lawyer's role, Lord Brougham's proposition in the Queen Caroline divorce trial, that:

An advocate, in the discharge of his duty, knows but one person in all the world, and that person is his client. To serve that client by all means and expedients and all hazards and costs to other persons, and among them, to himself, is his first and only duty; and in performing this duty, he must not regard the alarm, the torments and the destruction which he may bring upon others.[sic] $]^{67}$

\section{Major, ibid.}

M. Eberts, "Representing Unpopular Interests in the 1990s" (1993 Wickwire Lecture, Dalhousie Law School, 15 November 1993) [unpublished]; Hutchinson, supra note 4. Nondisclosure" (1991) 5 Geo. J. Legal Ethics 435 provides one forum for a discussion of such an idea.

67 G. Hazard, Jr. \& D. Rhode, The Legal Profession: Responsibility and Regulation, 3d ed. (Westburg, N.Y.: The Foundation Press, 1994) at 136-37 [emphasis added]. 
This expansive and inclusive conception of "do no harm" is premised on the idea that, as social beings and citizens, we are part of an interdependent web of relationships that generates responsibilities to others beyond those with whom we directly interact. This principle of non-maleficence ${ }^{68}$ suggests that we should be more empathetic in our practices to recognize that we owe a duty of care not just to our clients, but also to others who we can reasonably foresee will be harmed by our practices. To the extent that the proposition "do no harm" is tortious and communitarian rather than contractualist and individualistic, it may prompt us towards "compassionate immersion and non-indifference. ${ }^{1169}$

To be clear, however, this is not an attempt to impose a "stifling despotism of virtue"70 $^{\text {"70 }}$ where "mercenaries for hire" are transformed into "missionaries for justice." ${ }^{71}$ It is not proposed that lawyers put other interests ahead of their clients'. Rather the proposition is more modest: work in your client's best interest but only up to the threshold of not harming others. It is not an invocation to do good; it is an exhortation not to do wrong. ${ }^{72}$

Tosh Hayashi has brought this way of phrasing the issue to my attention.

Nussbaum, supra note 24 at 744.

R.M. Unger, "The Critical Legal Studies Movement" (1986) 103 Harv. L. Rev. 561 at 641.

Rhode, supra note 42 at 632.

Negotiation strategies might be a fruitful area of analysis. See e.g. T. Guernsey, "Truthfulness in Negotiation" (1982) 17 U. Richmond L. Rev. 99. An obvious response to this suggestion is that not every lawyer will adopt such a stance, and that those who are less ethically motivated will service those clients who want a "hired gun," thereby free-riding in this new "ethical economy." Gordon and Simon identify this potential problem and respond to it in the following manner:

Here the image is of a "race to the bottom" in which moral entrepreneurs will undercut others in a competitive process that will push standards down to their least common denominator.

To the extent that clients shop for lawyers in terms of their willingness to do the clients' bidding, there is some reality to this view. But to the extent that clients value high ethical standards in lawyers, the view ignores countervailing pressures. Clients might value high ethical standards in lawyers because they themselves have such standards and prefer to associate with people who share their views. They may value high standards because they believe such standards are associated with an especially sophisticated type of legal judgment that is less likely to sacrifice the client's long-term interests to short-term gain. They may value them because association with lawyers with a reputation for high standards lends the client valuable status or credibility with third parties with whom the client has to deal.

If high standards have economic value in this sense, lawyers have practical reasons to institutionalize them through organizations like bar associations and to give them credibility by conferring powers to certify and enforce them on such associations. Thus, one might imagine a "race to the top" in which entrepreneurs make their services more attractive by associating them with a credible reputation for high ethical standards, thus creating competitive pressures for others to follow suit. As more lawyers follow suit, association with those who do not will carry an increasingly costly stigma that deters clients and marginalizes this type of practice. Of course, this vision is no more plausible than the "race to the bottom." It seems likely that any market for legal services will involve pressures pushing ethical standards in many directions. The point is that these conflicting pressures may leave ambitious lawyers some room for institutional innovation that furthers their 


\section{LOCATING LEGAL ETHICS}

I think that the foregoing review suggests two things: first, that it is possible to talk about ethics and to outline some procedural and substantive ethical guidelines; and second, that ethics are plural and diversified, contingent upon the nature of the law job involved. In this section, I will attempt to locate the ethical triad of "critical selfreflexivity," "responsibility" and "do no harm" in the context of several different aspects of the legal profession, while drawing upon several of the presentations and debates that have surfaced in the last few days. A connecting theme for the ensuing suggestions is that ethical lawyering is like a muscle: it can be toned through regular exercise, or it can atrophy through disuse. ${ }^{73}$

\section{A. LEGAL EDUCATION}

Legal education, not only in law schools but also in the form of CLE, is an obvious and important location for a consideration of questions of professional responsibility. ${ }^{74}$ There are, of course, the debates about what is the best way to structure professional responsibility courses and the contentious question of whether or not they should be mandatory. ${ }^{75}$ But I think it is important to emphasize that legal educators need to conceive of professional responsibility expansively and critically and not just to consider it as a forced march through codes of conduct. For example, as teachers we must emphasize that much professional misconduct is not just moral laxity, but a form of white collar crime. Moreover, as professors, we have to take responsibility for questions of access to legal education, ${ }^{76}$ for what we choose to teach and for what we choose not to teach, ${ }^{77}$ for how we teach and the ways we create safer or more hostile

ethical ideals.

R. Gordon \& W. Simon, "The Redemption of Professionalism" in R. Nelson et al., eds., Lawyers' Ideals/Lawyers' Practices: Transformations in the American Legal Profession (Ithaca: Cornell University Press, 1992) 230 at 245.

This theme is suggested, indirectly, by D. Kennedy, "Rebels from Principle: Changing the Corporate Law Firm from Within" (Fall 1981) Harvard Law School Bulletin 36 at 39 . While developing this metaphor, I have wondered (in a self-reflexive way) whether it is potentially abilist. Having discussed it with several colleagues, I don't think it is, but I am not completely sure. Therefore, because I believe it is a helpful metaphor, I have decided to use it. W. Cotter, Professional Responsibility Instruction in Canada: A Coordinated Curriculum for Legal Education (Montreal: Conceptcom, 1992).

A. Esau, "Teaching Professional Responsibility in Law School" (1988) 11 Dalhousie L.J. 403.

R. Devlin, "Towards An/other Legal Education: Some Tentative Critical and Tentative Proposals to Confront the Racism of Modern Legal Education" (1989) 38 U.N.B.L.J. 89; R. Devlin \& A.W. MacKay, "An Essay on Institutional Responsibility: The Indigenous Black and Micmac Programme at Dalhousie Law School" (1991) 14 Dalhousie L.J. 296; Touchstones, supra note 26.

For example, in conjunction with the IBM programme, Dalhousie Law School has set in place a process of course revision to ensure that our teaching materials are more inclusive of diversity. Many professors have not attempted to incorporate such materials. It should also be noted that some of these materials, the point of which was to address racial discrimination, were reproduced in a barely legible way therefore making them quite inaccessible to visually impaired students. This poignant example of "still not getting it" was brought to my attention by Professor D. Pothier. 
environments, ${ }^{78}$ and for the implicit messages which we convey through our teaching. ${ }^{79}$ Furthermore, law teachers might want to consider making it a requirement that students fulfil some public service prior to graduation. ${ }^{80}$ The desired aim throughout, I would suggest, is to be prophylactic: to help students identify problematic assumptions and practices, not so much to create moral fibre (for that is an impossible task) but to encourage a environment hospitable to its growth. My colleague Wayne MacKay dealt with some of these issues more eloquently than $\mathrm{I}^{81}$

\section{B. LAW STUDENTS}

Many of the debates around professional responsibility tend to treat students as objects of discussion and therefore as essentially passive. Students, however, are active members of the legal community and also have much to contribute to the questions of professional responsibility. Two comments are all that I have time for in this report. First, it seems to me that it is important for students to realize that legal education is a social privilege and not an (inherited) right. One consequence of this could be that "mainstream students" might cease their complaining about the unfairness of "equity" initiatives at many Canadian law schools. Second, although times are tough, law students still represent a very privileged and quite "marketable" sub-community. This enables law students as a group to have some social power and to consider whether they can exercise that power in an ethically responsible way. To take one example, during the late 1980s, elite law students in the United States boycotted a major law firm because it was the legal representative of South African Airlines. The strategy contributed to the firm terminating its relationship with the South African government. ${ }^{82}$ Could such a campaign be organized in relation to equity issues in Canada, given the fact that many private law firms are refusing to even open the door?

\section{LAWYERS}

Lawyers, as both members of a professional community and individuals, obviously encounter many ethical questions. As a community, a collective commitment could be made to allocate a specific amount of our resources to pro bono work, ${ }^{83}$ or we could accept the LSUC proposed rule on non-discrimination. ${ }^{84}$ As individuals, we could

R. Devlin, "Legal Education as Political Consciousness-Raising or Paving the Road to Hell" (1989) $39 \mathrm{~J}$. Legal Educ. 213. See also D. Herman, "Legal Education, Feminism and the 'Well Intentioned Man': A Response to Richard Devlin" (1990) 40 J. Legal Educ. 257; Touchstones, supra note 26. E. Dvorkin, J. Himmelstein \& H. Lesnick, Becoming a Lawyer: A Humanistic Perspective on Legal Education and Professionalism (St. Paul, Minn.: West Publishing Co., 1981).

R. Smith, "Legal Utopia and Myopia: Some Comments Regarding Shiffrin, Lipkin and Looking Beyond the Mark in Legal Education" (1990) 19 Cap. U.L. Rev. 1059 at 1085. Sarat reports, for example, that 70 percent of the students who enter Harvard Law School wanted to practice public interest law, but only 2 percent actually do: A. Sarat, "Law's Two Lives: Humanist Visions and Professional Education" (1993) 5 Yale J. L. \& Human. 201 at 203.

A.W. MacKay, "Some Thoughts on a More Humanist and Equitable Legal Education" (1995) 33 Alta. L. Rev. 920.

Simon, "Ethical," supra note 42 at 1130; Kennedy, supra note 42 at 1158.

Major, supra note 12.

Curtis, supra note 5. 
reconsider how we run our daily practices to analyze the ways in which we are exclusive and dominating. As potential remedies, we might encourage employment equity and mentoring as possibilities. ${ }^{85}$ We might also want to rethink the ways in which we interact with our clients. Instead of considering them as merely fountains for billable hours, we could encourage them to pursue self-help and empowerment rather than dependence. Or, we could drop the pretence of "agnosticism" and "studied neutrality"86 and suggest to clients that, while what they propose to do would be legal, it would be "conduct unbecoming" a lawyer to pursue such a strategy as it harms other members of society. ${ }^{87}$ Finally, if we are in relatively senior positions in a law firm (for example, a partner), we could promote procedures to recognize and value the pro bono efforts of the lawyers who work with us, ${ }^{88}$ or implement parental leave policies and flexible work schedules. ${ }^{89}$

\section{JUDGES}

Judges, as the elite of the profession, are particularly well situated to provide ethical leadership. They could accept that bias does in fact exist in the court system ${ }^{90}$ and embrace rather than trash judicial education programs that are designed to promote equity in the legal system. ${ }^{91}$ Moreover, as leaders of the profession, they could acknowledge rather than deny that on occasion there is inappropriate judicial conduct and that a modernized and more nuanced disciplinary process is desirable and necessary. ${ }^{92}$ In the courtroom, judges could restrict some of the excesses of the adversary system. Examples might include modified procedures when aboriginal persons are involved ${ }^{93}$ or the curtailment of excessively adversarial tactics in cases

Ibid:; Watson Hamilton, supra note 5; Major, supra note 12; Touchstones, supra note 26.

Rhode, supra note 42 at 621.

For those who have a penchant for precedent, it has been said that Abraham Lincoln, as a young lawyer, advised a potential client as follows:

Yes, we can doubtless gain your case for you; we can set a whole neighbourhood at loggerheads; we can distress a widowed mother and her six fatherless children and thereby get you six hundred dollars to which you seem to have a legal claim, but which rightfully belongs, it appears to me, as much to the woman and her children as it does to you. You must remember that some things legally right are not morally right. We shall not take your case, but will give you a little advice for which we will charge you nothing. You seem to be a sprightly, energetic man; we would advise you to try your hand at making six hundred dollars in some other way.

D. Luban, "The Lysistratian Prerogative: A Response to Stephen Pepper" (1986) Am. Bar Found.

Res. J. 637.

Major, supra note 12.

Baker, supra note 38; A. Rauhala, "Making Room for Lawyers with Children" Globe and Mail (21 July 1993) A2; K. Selick, "Why Should Law Firms Subsidize Mums?" Globe and Mail (19 July 1993) A13; Touchstones, supra note 26.

K. Czapanskiy, "Gender Bias in the Courts: Social Change Strategies" (1990) 4 Geo. J. Legal Ethics 1; Giesel, supra note 5 at 780; J.A. Levine, "Preventing Gender Bias in the Courts: A Question of Judicial Ethics" (1988) I Geo. J. Legal Ethics 775; Touchstones, supra note 26.

The initiatives of the Western Judicial Education Centre are helpful in this regard.

But see contra C. Schmitz, "Judges 'strongly' opposed to C.B.A. plan for Judicial Discipline Reforms" Lawyers' Weekly (16 September 1994) 1 at 43.

Chartrand, supra note 45. 
involving violence against women. ${ }^{94}$ In the latter context, at a very minimum, judges could ensure that they and their peers stop blaming the victim. ${ }^{95}$ On a different tack, judges could be more hospitable to malpractice suits brought against members of the legal profession. ${ }^{96}$

\section{E. BENCHERS}

Benchers, as the embodied custodians of the conscience of the legal profession, have perhaps the greatest responsibility to go beyond the rhetoric of professional ethics, "to walk their talk."97 The most significant opportunity and test for determining this possibility revolves around the question of self-regulation. As I interpret the evidence, it appears that self-regulation has not worked sufficiently well to satisfy public needs. ${ }^{98}$ Moreover, despite the fact that the law societies are (theoretically) meant to protect "the public interest," that hardly appears to be the viewpoint of many of their members who, to the contrary, see law societies as protectors of the profession's parochial interests. ${ }^{99}$ Consequently, I would encourage benchers to consider "a system of multiple controls"100 where justice is not only done but is manifestly seen to be done. Various options might include: review by judges, review by an ombudsperson, empowered lay representation, regulatory controls and greater openness to tortious, contractual and fiduciary actions. ${ }^{101}$ In particular, assistance might be garnered from Quebec's Office des Professions. ${ }^{102}$ At an absolute minimum, as Wilkins points out,

Ginn, supra note 47.

Ibid.

R. Anderson \& W. Steele, "Fiduciary Duty, Tort and Contract: A Primer on the Legal Malpractice Puzzle" (1994) 47 S.M.U. L. Rev. 235; I. Miller, "Breaking the Written Code of Silence in Legal Malpractice Settlements" (1992) 6 Geo. J. Legal Ethics 187.

Hutchinson, supra note 4; MacKay, supra note 81.

Arthurs, supra note 20; D. Kleinberger, supra note 45 at 366-67; R. Laperrière, "L'Éthique et la Responsibilitie Professionnelle des Juristes En Matière de Compétance" (1995) 33 Alta. L. Rev. 882; Law, supra note 23; G. Mew, "Lawyers: The Agony and the Ecstasy of Self-Government" (1989) 9 Windsor Yearb. Access to Justice 210; Rhode, supra note 50 at 692-706; Wilkins, supra note 30 at 866-67.

Curtis, supra note 5. Curtis makes the point that benchers no longer are comprised of "elder statesmen and are now more like representatives of different constituencies [within the legal profession]" at 790. To my mind, this is an improvement for two reasons. First, it represents a move from feudalism to democracy within the profession. Second, the shift makes it apparent that benchers are representatives of the profession and therefore that the interests of the general public need to be protected by a system of checks and balances beyond those of the internal regulatory mechanisms of the profession. See also Arthurs, supra note 7; Watson Hamilton, supra note 5; Pue, supra note 6.

Wilkins, supra note 30.

Anderson \& Steele, supra note 96; American Bar Association Commission on Evaluation of Disciplinary Enforcement, Lawyer Regulation for a New Century (Chicago: American Bar Association, 1992); Pue, supra note 6; Wilkins, ibid. Undoubtedly each of the suggested options has its own problems. It is beyond the scope of this paper to canvass their various strengths and weaknesses. My argument is that it is desirable to assess such possibilities rather than simply refusing point blank to contemplate any change in the status quo.

Y.M. Morrissette, "Address on Alternative Visions of Legal Professionals in Society" (Address to A New Look: A National Conference on the Legal Profession and Ethics, Calgary 10 June 1994) [unpublished]. 
"enforcement proceedings should presumptively be open and accessible to ensure that information about the conduct in question and the standards being applied can be reviewed and critiqued." 103

\section{F. LEGISLATURES}

While there is much to be done within the profession, responsibility does not rest with the profession alone. In light of the failures of the legal marketplace, corrective interventions might well be required by the legislatures. For example, given the apparent intransigence of the profession on improved regulation, perhaps the time is ripe for the creation of autonomous review mechanisms for alleged misfeasances. ${ }^{104}$ Alternatively, steps could be taken towards curtailing the profession's monopoly over access to legal services. ${ }^{105}$ More ambitiously, socialized law might be an appropriate approach, for example, through the fostering of prepaid legal services ${ }^{106}$ and enhanced funding for legal aid. ${ }^{107}$ At a minimum, lawyers who do legal aid work ought to be promptly paid. ${ }^{108}$

\section{G. SUMMARY}

To summarize, in this section I have attempted to develop two arguments. The first is that responsibility for the improvement of legal services lies primarily (but not exclusively) with those who are within the system, not with outsiders. Far too often

Wilkins, supra note 30 at 884 .

$104 \quad$ Rhode, supra note 50 at 721.

A rather nice example of this intransigence occurred in my own law school as I worked on a final draft of this essay. Dalhousie has a first year course entitled "Orientation to Law" in which professors give 90 minute lectures on an area of particular interest to them. Students are subsequently interviewed by faculty members who quiz them on the various presentations made. To provide a common base for evaluation each professor provides several questions and suggested answers. A prominent member of the Nova Scotia Bar (who also attended this Conference) gave the lecture on Professional Responsibility, and provided the following questions and answers:

1. What are the essential obligations of all Law Societies?

[Answer: Admitting lawyers to the profession, setting standards for lawyers to follow, disciplining lawyers who get into trouble.]

2. Why is it important that the legal profession remain independent?

[Answer: Only a profession which is free from the threat of Government interference can fairly argue against the State and preserve the rights and privileges of individuals in the State.]

3. In whose interest does the legal profession govern itself?

[Answer: The primary goal of all Law Societies is to self govern the legal profession in the public interest.]

For a powerful demolition of such doctrinaire arguments, see Pue, supra note 6.

Simon, "Ideology," supra note 42 at 141; S. Thom, "What to do about Paralegals" (March 1993)

28 L. Soc. Gaz. 34; "N.S. Barristers' Society Sends Paralegals Stern Warning" Lawyers Weekly (17 March 1989).

R. Pearce, P. Shea \& J. Stempel, "An Assessment of Alternative Strategies for Increasing Access to Legal Services" (1980) 90 Yale L.J. 122; E. Dennis, "Prepaid Legal Plan Gains Support: Lawyers Worried" [Halifax] Mail Star (2 September 1986) 7. 
power holders resist change by continually deferring responsibility to those who are excluded. This is the familiar "What's the problem? Prove it! Can you do it for us, please?" response. While we should not ignore what is being said by the communities which we serve and should do whatever is feasible to enhance their input, the processes of renewal and revision can (with just a little imagination and good will) be set in place immediately. My second proposition is that the time has now come to stop considering legal ethics as simply a "private" moral code internal to the profession and to reconceive them as enforceable "public" norms. A cloistered aristocracy is an anachronism in an egalitarian and democratic society.

\section{CONCLUSION}

By way of conclusion, I want return to the neologism of pessoptimism. The structure of my analysis and the substance of my comments have, in the main, emphasized the optimistic dimension of the equation. I have suggested that a serious pursuit of professional ethics requires reflection and reorientation on many different fronts: on the micro level and the macro level, in the structure of the legal profession and in our individual characters. Rather than yearning for a mythical "golden age of professionalism," I have attempted to argue that we should be open-minded and forward looking in our planning. Conversations such as those generated by this conference signify that some progress is, perhaps, being made.

But, at the same time, I think that it would be an error to get too starry-eyed by resting my report on idealistic voluntarism. I have two reservations: first, my sense of the inevitable tells me that debates about professional ethics are fine on a Saturday afternoon, but on Monday morning it will all seem very naive, or at best, something to be put on the back burner. As many participants (both optimistic and pessimistic) have pointed out, a major problem is that the provision of legal services is less about providing reflective and skilful advice, than it is about the selling of a commodity. ${ }^{109}$ Contemporary legal practice does not focus on the needs of a client; rather it focuses on time. Such an approach priorizes efficiency and wealth maximization over quality and care. The result is that many of us in the legal community suffer from a sort of double consciousness: on the one hand, we espouse the virtues of professionally responsible behaviour; yet, on the other hand, due to pressing practical demands, we have neither the time nor the energy to mobilize processes that would be conducive to fostering a more ethically responsible environment. In other words, the commodification of law renders our efforts demoralizing.

Second, to emphasize and prioritize ethics is not cost-free. A regulated profession will be expensive; increased consumer remedies will drive up professional liability insurance costs to lawyers. ${ }^{110}$ The impact could be twofold. Lawyers might, in turn, reallocate such costs to consumers, making access to law even more expensive than it already is; or, small-time lawyers may be forced out of business, again making access 
that much more difficult. Such costs cannot be avoided by wishful thinking. ${ }^{111}$ However, an awareness of costs should not be raised as an insurmountable barrier to the possibility of enhanced professional responsibility. Rather, costs are but a variable that must be factored into the necessarily complex social equation.

Finally, I want to suggest that pessoptimism counsels neither crude economic determinism $^{112}$ nor ahistorical sentimentalism. ${ }^{113}$ It is not redemptive ${ }^{114}$ in its orientation, nor is it grounded in anti-professionalism. ${ }^{115}$ Rather, pessoptimism advocates a realistic and contextualized analysis which argues that lawtalk and legal practice are terrains of social, economic, political and moral contestation. Those of us who are engaged in the practices of law always and already (if inchoately) know this. It is through conferences such as this that we can bring these contestations to the fore in a struggle for professional reformation and realignment. The result, I would hope, is that even if we cannot agree how we can do more good, we might at least agree how we can do less harm.

III M. Trebilcock, "Economic Analysis of Law" in R. Devlin, ed., Canadian Perspectives on Legal Theory (Toronto: Emond Montgomery Publications, 1991) 122.

$112 \quad$ Abel, supra note 7.

113 A. Kronman, The Lost Lawyer: Failing Ideals of the Legal Profession (Cambridge, Mass.: Belknap Press, 1993).

$114 \quad$ Gordon \& Simon, supra note 72.

115 "Anti-Professionalism" in S. Fish, Doing What Comes Naturally: Change, Rhetoric, and the Practice of Theory in Literary and Legal Studies (Durham, N.C.: Duke University Press, 1989), c. $11,215$. 